Khazanah: Jurnal Studi Islam dan Humaniora

ISSN: 0215-837X (p); 2460-7606 (e), Vol. 17 (2), 2019, pp. 245-262

DOI: $10.18592 /$ khazanah.v17i2.3130

Submit : 15/08/2019 Review : 25/09/2019 Publish : 31/12/2019

\title{
THE STRATEGY OF PREVENTING RADICALISM THROUGH REINFORCEMENT OF THE MOSQUE TAKMIR MANAGEMENT BASED ON ASWAJA ANNAHDLIYAH
}

\author{
Hamidulloh Ibda \\ STINU Temanggung, Central Java \\ h.ibdaganteng@stainutrng.ac.id \\ Ziaul Khaq \\ IAIN Pekalongan, Central Java \\ zaulhaque@gmail.com
}

\begin{abstract}
This article aims to discuss the strategies of radicalism preventing in mosques through strengthening Aswaja Annabdliyah's Islamic-based of mosque takmir management that is tolerant, moderate, and upholds the Islamic principle of Rabmatan Lil-alamin. This field research uses descriptive qualitative method. Data collection was obtained from interviews and observations. The results of the study mentioned that from 104 mosques in Kandangan Subdistrict, Temanggung Regency, only 96 mosques had been noted in the Nabdlatul Ulama Mosque Takmir Institute (LTM NU), while 8 other mosques had been not. After the research was carried out, four mosques were joined and had become members of the NU LTM and implemented the takmir management of the Aswaja Annabdliyah based mosque. There are seven strategies carried out, namely; (1) strengthening management of the ideals (management of the physical building of the mosque), imarah (management of the activities of the mosque), and riayah (management of mosque hygiene), (2) forming LTM NU at the sub-district and village level, (3) forming management of mosques takmir by involving all elements, (4) making syllabus/ curriculum for worship timetable, education and ritual activities, (5) giving tasks to takmir to maximize mosque functions, (6) strengthening administration management and symbolizing mosques, (7) strengthening social economic empowerment in mosques. The strategy of strengthening the takmir of mosques management has been aligned with Talcott Parsons' structural functionalism theory with schemes adaptation, goal attainment, integration, and latency (AGIL). There are challenges and opportunities that faced. In the internal aspects, namely limited access to the city center, low human resources, and lack of comprehensive knowledge about the management of takmir of mosque External aspects, namely the existence of four mosques still controlled by radical Islamic groups, and often there are religious studies in mosques from radical groups.
\end{abstract}

Keywords: Radicalism; Takmir Management; Aswaja Annabdliyah Islam.

\section{Introduction}

As a place of worship for Muslims, mosques must clear of radicalism, both aspects of fikrah (thoughts/teachings), aqidah (beliefs), barakah (movements), and amaliyah (rituals of worship). At present many mosques in Indonesia have been controlled by radicals who teach conservative and transnational ideologies that contradictory with Islam and the constitution of the Unitary State of the Republic of Indonesia (NKRI). Starting from the contents of the lecture, inserting radical 
lecturers, to infiltrate the management of mosques, from state mosques, major mosques, grand mosques, large mosques, Jami mosques, historical mosques, mosques in public places, and national mosques.

Mosques should spread tolerance and peace according to Islamic principles rabmatan llil-alamin, not proclaim the message of division through various lectures under the guise of Islam. Not only inviting lecturers who are affiliated with banned organizations such as Hizb ut-Tahrir Indonesia (HTI), the spread of radical ideas has now entered the mosque with a mode of infiltrating the management of the takmir of mosque. The National Intelligence Agency (BIN) in 2018 found 41 mosques in the government area were influenced by radicalism. The data was based on the results of a survey of the Nahdlatul Ulama Islamic Boarding School and Community Development Association (P3M). ${ }^{1}$

The mode of dissemination of radical ideas is carried out by preachers preaching in mosques with radical narratives, intolerance, hate speech, quoting verses of war and invitations to support the Islamic State of Iraq and Sham (ISIS). This case was dominant in the State-Owned Enterprises (BUMN) office mosques, state institutions, and ministry offices. Of the 41 mosques, BIN explained that the P3M survey found 17 mosques in the high radical category, 17 moderate radical category, and 7 low radical categories. BIN indicated that the spread of radicalism also occurred on 7 campuses according to the results of a survey of 50 state universities in 15 provinces in Indonesia. ${ }^{2}$

The spread of radicalism on the campus among of them was through the Campus Da'wah Institution (LDK) which became the engine for the formation and expansion of cadres of Islamic political movements, the Ikhwanul Muslimin and Hizb ut-Tabrir to achieve their ideological ambitions. The movement is a dangerous threat to moderate Islamic in Indonesia. ${ }^{3}$ From the research carried out, moderate Islamic activists tried to secure the organization to be safe from radicals including mosques within the campus itself.

The culmination of radicalism is terrorism which was lead to the act of killing through bombing. At least the last ten years, a series of acts of terror that have taken place have made Indonesia and Malaysia a country that has a "red light" from the global world. In the Asian region, Indonesia and Malaysia are the two most important fields in the study of terrorism and religious radicalism. ${ }^{4}$ The

\footnotetext{
${ }^{1}$ Devina Halim, 'Penjelasan BIN soal 41 Masjid di Lingkungan Pemerintah Terpapar Radikalisme', KOMPAS.com, accessed $20 \quad$ December https://sains.kompas.com/read/2018/11/20/19443281/penjelasan-bin-soal-41-masjid-di-

lingkungan-pemerintah-terpapar-radikalisme.

${ }^{2}$ Felix Nathaniel, 'Soal Masjid Terpapar Radikalisme, BIN: Yang Radikal Penceramahnya', Tirto.Id, November 2018.

3Ilyya Muhsin; Nikmah Rochmawati; Muhammad Chairul Huda, 'Revolution of Islamic Proselytizing Organization: From Islamism to Moderate', Qudus International Journal of Islamic Studies 2019 7, no. 1 (2019): 45, http://dx.doi.org/10.21043/qiijis.v7i1.5076.

${ }^{4}$ M. Zaki Mubarok; Ahmad Fauzi Abdul Hamid, 'The Rise of Radicalism and Terrorism in Indonesia and Malaysia', RISEA :Review of Islam in Southeast Asia 1 (2018): 29.
} 
phenomenon of radicalism, extremism, and terrorism that is currently sweeping the Southeast Asian region is indeed ironic, even though this region is known as a country that has a diversity of ethnicities, languages, cultures and religions. The dynamics disrupt the democratization process which must be stopped immediately. ${ }^{5}$ It is ironic if Indonesia still surrounded by radical movements in the name of religion, especially to be in campuses and mosques.

The radical Islamic movement is a movement that has a mindset of textual ideology, takfiri (A Muslim who declares another Muslim to be apostate and therefore no longer a Muslim) and truth claim. They think they are right themselves and others are wrong. Outside of their ideology is deemed deviant, because it is considered contrary to the Qur'an and Sunnah. This dynamic does not reflect the substance of Islam and the peace of Islam itself as the teachings of the Prophet Muhammad, that Islam is a religion of mercy for all nature. ${ }^{6}$ Not only the relationship between humans and God and nature but the relationship among human beings have been taught by Islam in a way of living peacefully regardless of background.

Unfortunately, a very tolerant Islam turns into "radical" because of the actions of a few individuals. As an example of a survey of the Center for Islamic and Community Studies (PPIM) UIN Jakarta which found 78 percent of teachers agreed with the sharia government, 77 percent agreed to support organizations that implement sharia and 18 percent disagree with Pancasila and the 1945 Constitution in line with sharia." "Islam and nationalism" and "Islam and Pancasila" are final, because the Pancasila substance is Islamic. Muslim should not appear on the surface, but on the substance. Even worse, the practice of radicalism has been carried out in mosques, where Muslims worship, which should be the embryo of peace.

Research mentions the practice of Islamic teaching and the perception of the committee of the mosque is close to radicalism. The findings of this study denote that the phenomenon of neo-fundamentalism grows and develops in office mosques. Evidently, there are scriptural and literal interpretations, the importance of accepting the formal implementation of Islamic law, hatred of Jews and Christians and the rise of young actors of Islamic fundamentalism. Another findings mention that there is a Tarbiyah movement, a child of the Ikbwanul

${ }^{5}$ Muhammad Nida' Fadlan; Rangga Eka Saputra, 'Islam, Radicalism, Democracy, and Global Trends in Southeast Asia', Studia Islamika 24 (2017): 644, https://doi.org/10.15408/sdi.v24i3.6566.

${ }^{6}$ Muhammad Ulil Abshor, 'Peran Sufisme Dalam Mengatasi Paham Islam Radikal Di Indonesia', Al-Banjari: Jurnal Ilmiah Ilmu-Ilmu Keislaman 18 (2019): 153, https://dx.doi.org/10.18592/al-banjari.v18i1.2540.

${ }^{7}$ Dirga Maulana, 'The Exclusivism of Religion Teachers: Intolerance and Radicalism in Indonesian Public Schools', Studia Islamika 24 (2017): 399, http://dx.doi.org/10.15408/sdi.v24i2.5707. 
Muslimin ideology found in the mosque teaching process. If it is left unchecked and not monitored, it will destroy the state of tolerant and peaceful Islam. ${ }^{8}$

Islamic radicalism is a really political cage. Then religion must be returned as a moral source. Islam must be able to bring peace and harmony, enabling people of any race, languages, ethnicity, cultures, ethnicity and even religions to sit together and achieve common goals. Religion is an inspiration for justice seekers with the concept of equality, respect, and tolerance. ${ }^{9}$

Radicalism is the enemy of religious life in Indonesia. Although many strategies to prevent radicalism have been initiated, especially with a security approach, it turns out that radicalism still exists and develops in Indonesia. ${ }^{10}$ The proof is that radicalism in Southeast Asia, especially in Indonesia, still exists. Naturally, if Indonesia turns into a subject of an alleged nest of radicalism and terrorism. There are four factors that cause the rise of Islamic radicalism in Indonesia. First, the political repression of the regime. Second, socio-economic deprivation. Third, globalization. Fourth, transnational networks that invite residents not to become Indonesian citizens. ${ }^{11}$

Radicalism arose because of the mission of purifying Islam that returned to the Qur'an and the Sunnah. Radicalism has classes, from the level of only the teachings of violence, thoughts, practices of worship, to carry out bombings. The radicalism referred to here is not only from the personal terrorist or the perpetrator of radicalism itself. But also the structured, systematic and massive movements carried out by radical organizations. In the fact, Islam and nationalism, Islam and culture have become one breath, and Islamic purification efforts are identical to radical movements because they are instant and do not hold the principle of religious truth and state truth. Right radical movements can be seen such as the Hizb ut-Tahrir Indonesia (HTI), Indonesian Mujahidin Council (MMI), Islamic Defenders Front (FPI), Salafi Movement, Laskar Jundullah, Laskar Jihad, Jamaah Ansharut Tauhid (JAT), Indonesian Islamic State (NII). ${ }^{12}$

Another opinion said that six radical organizations must be watched out and even disbanded. These mass organizations clearly contradict the Pancasila as the basis of the state. These six organizations did not uphold peace and tolerance, on the contrary, they actually provoked for the sake of division as if they wanted to

${ }^{8}$ Ridwan Al-Makassary, 'Examining Jakarta Office Mosques: Islamic Teaching Practices and Views of Islamic Ideological Issues', IJIMS: Indonesian Journal of Islam and Muslim Societies 3 (2013): 122, http://dx.doi.org/10.18326/ijims.v3i1.121-148.

${ }^{9}$ Abd A'la, 'The Genealogy of Muslim Radicalism in Indonesia: A Study Of The Roots And Characteristics of the Padri Movement', Journal of Indonesian Islam 2 (2008): 296, http://dx.doi.org/10.15642/JIIS.2008.2.2.267-299.

${ }^{10}$ Syamsul Arifin, 'Islamic Religious Education and Radicalism in Indonesia: Strategy of Deradicalization Through Strengthening the Living Values Education', Indonesian Journal of Islam and Muslim Societies 6 (2016): 94, http://dx.doi.org/10.18326/ijims.v6i1.93-126.

${ }^{11}$ Akh. Muzakki, 'The Roots, Strategies, And Popular Perception Of Islamic Radicalism In Indonesia', Journal of Indonesian Islam (JIIS) 8 (2014): 19, http://dx.doi.org/10.15642/JIIS.2014.8.1.1-22.

${ }^{12}$ Sun Choirol Ummah, 'Akar Radikalisme Islam Di Indonesia', Humanika: Kajian Ilmiah Mata Kuliah Umum 12 (2012): 119, http://dx.doi.org/10.21831/hum.v12i1.3657. 
move the conflict in the Middle East to Indonesia. Starting from Hizb ut-Tahrir Indonesia (HTI), Anti-Shia National Alliance (ANNAS), Jamaat Ansarut Tauhid (JAT), Indonesian Mujahidin Council (MMI), Islamic Community Forum (FUI), Islamic Defenders Front (FPI). ${ }^{13}$

Mosques as places of worship for Muslims must be sterile from radicalism in the name of Islam. The role of the takmir must be clear and systematic to teach tolerance and peace as suggested by the Central Java Governor Ganjar Pranowo in 2016. He recommended that the takmir of the mosque should be strengthened by its management because there were many radical leaflets found in mosques. The role of takmir of the mosque is currently important. The role of the mosque in tackling terrorism and radicalism must function properly. For that, do not let the takmir leave the mosque in the position of no administrator. ${ }^{14}$ Director of Prevention of the National Counterterrorism Agency (BNPT) Brigadier General Police Hamli in 2018 also appealed to mosques to be free from radicalism, especially mosques on campus. The solution is to strengthen the takmir of the mosque as an institution in the mosque..$^{15}$

Some studies in Banten mentioned that the mosque is functioned for religious activities, recitation, facilities for social activities, such as deliberations and educational activities. The role of the mosque in substance and action can manifest the teachings of Islam that are rahmatan lil-alamin which is based on local wisdom. Generally, the role of the mosque is able to make a positive contribution to strengthening social religious values and avoiding radicalism there, in this research was found that the role of mosques can be a social institution that plays a role in counteracting religious radicalism through strengthening the socio-economic aspects of the Islamic community. The reason is the trigger factor for Islamic radicalism in Indonesia due to social inequality. ${ }^{16}$

Strengthening education, training, and guidance through periodic ties to youth mosques is also one of the solutions to prevent the development of radicalism and terrorism. ${ }^{17}$ Then the mosque must be fixed to return to its proper function, which is to be the center of the activity of the spread of moderate Islam which is rahmatan lil-alamin. Takmir as an institution that houses mosques must be managerially and technically strong. Takmir is an administrator, lecturer, and even

\footnotetext{
${ }^{13}$ Tsamara Amany, “Ini Dia 6 Ormas Yang Harus Dibubarkan Pemerintah"”, Redaksiindonesia.Com, January 2016.

${ }^{14}$ Stefi Thenu, 'Selabaran Radikal Di Masjid Harus Ditangkal', Beritasatu.Com, November 2016.

${ }^{15}$ Rama Prasetyo W, 'Pengurus Takmir Kampus Di Purwokerto Dilibatkan Untuk Pencegahan Gerakan Radikalisme’, Rri.Co.Id, October 2018.

${ }^{16}$ Muhammad Syafar, 'Pemberdayaan Masyarakat Berbasis Masjid Untuk Menangkal Radikalisme Islam Di Banten', Lembaran Masyarakat: Jurnal Pengembangan Masyarakat Islam 4 (2018): 106-7, http://dx.doi.org/10.32678/lbrmasy.v4i2.1185.

${ }^{17}$ Mohammad Fahrur Rozi; Fajar Surahman, 'Internalisasi Nilai-Nilai Pendidikan Agama Islam Dalam Rangka Memperkokoh NKRI: Melawan Paham Radikalisme Dan Arus Isu Terorisme Di Remas Robiatul Adhawiyah Dan Remas Al-Falah Desa Ponteh Kecamatan Galis Kabupaten Pamekasan', Jurnal Pengabdian Masyarakat 4 (2019): 24, https:// doi.org/10.30996/jpm17.v4i1.1992.
}

Khazanah, Vol. 17 (2), 2019 
marbot can also be called takmir. ${ }^{18}$ However, in reality, not all takmir adhere to the principle of moderate Islam and even vice versa. They also do not understand the details of their duties, roles, and functions as guardians of mosques from radicals.

We can learn tolerance from Cheng Hoo Mosque, which is not just a building, but in its preaching system applies communication media literacy used by the Muslim Chinese community in Indonesia through the publication of Cheng Hoo Magazine, Whats App East Java PITI Forum, Website and Facebook that build tolerance. All media are used and have a significant impact on the relations, interactions, and communication between the Chinese Muslim community and Chinese nonMuslims and the Chinese Muslim community with non-Chinese Muslims in this country. The Chinese way of being a good Muslim is also seen in some Chinese community-based Islamic education services in Indonesia from kindergarten, Islamic elementary school, routine recitation and Islamic boarding schools. ${ }^{19}$ Mosques in Indonesia should be a center of tolerance and peace that does not contradict religion and culture, religion and nationalism.

In Indonesia, other than Muhammadiyah, Islamic organization that consistently adhere to Pancasila, Bhineka Tunggal Ika, NKRI, and the 1945 Constitution is Nahdlatul Ulama (NU). The organization founded by KH. Hasyim Asyari has long adhered to the Islamic ideology Ablussunnah Waljamaah Annabdliyah which is a Muslim who adheres to Imam Abu Hasan Asya'ri and the ulama of the schools such as the Hanafi Imam, Syafii Imam, Maliki Imam, and Hambali Imam. Aswaja Annahdliyah Islam can be referred to as the construction of religious thoughts and practices based on the Qur'an, traditions (sunnab) of the Prophet Muhammad, ijma'; qiyas, and others. ${ }^{20}$

In their life, adherents of Aswaja Annabdliyah Islam always prioritize the principles taught by the Prophet Muhammad and his companions. First, attawassuth, namely the midst, moderate, not extreme left or right. Second, at-tawazun, which is balanced in all respects, including in the use of aqli argument (the arguments from the rational mind) and the argument naqli (the arguments from the Qur'an and Hadith). Third, al-i'tidal or perpendicular. Fourth, tasamub which means tolerance. $^{21}$ In the social aspect, the NU community also uphold the principle of harmony. First, ukhuwah Islamiyah, namely brotherhood among Moslems. Second,

\footnotetext{
${ }^{18}$ Lembaga Takmir Masjid (LTM) Nahdlatul Ulama Kabupaten Temanggung, Buku Saku Takmir, 1st ed. (Temanggung: PCNU Temanggung, 2016), 11.

${ }^{19}$ Rahmawati Rahmawati; Kasim Yahiji; Choirul Mahfud; Jauharoti Alfin; Much Koiri, 'Chinese Ways of Being Good Muslim: From the Cheng Hoo Mosque to Islamic Education and Media Literacy', Indonesian Journal of Islam and Muslim Societies 8 (2019): 226-27, http://dx.doi.org/10.18326/ijims.v8i2.225-252.

${ }^{20}$ Aceng Abdul Aziz DY; M. Harfin Zuhdi Zamzami M; Afwan Faizin; Sulthonul Huda; Sulthon Fathoni, Islam Ablussunnah Waljama'ah (Sejarah, Pemikiran, Dan Dinamika NU Di Indonesia), II (Jakarta: PP Lembaga Pendidikan Ma'arif NU, 2015), 60-61.

${ }^{21}$ Muhyidin Abdusshomad, 'Karakter Tawassuth, Tawazun, I'tidal, Dan Tasamuh Dalam Aswaja', Nu.or.Id, March 2009.
} 
ukbuwah wataniyah, namely brotherhood among the same nation. Third, ukbuwah insaniyah, namely the brotherhood of mankind. ${ }^{22}$

As a large organization, NU has a special institution that handles mosques, namely the Nahdlatul Ulama Mosque Takmir Institution - Lembaga Takmir Mesjid Nabdlatul Ulama- (LTM NU) which is an institution under the coordination of NU in charge of implementing policies in the field of mosque empowerment and development. ${ }^{23}$ Until now, there is no news about the mosque under the LTM NU exposed to radicals. On the contrary, the mosque under NU actually adheres to the principle of moderate Islam and does not teach radicalism.

By using this concept, NU citizens are very well known for a long time and never betrayed Islam and the NKRI, so that it was impossible to carry out the purification of Islam by carrying out radical teachings especially supporting the establishment of a sharia or Khilafah state. If all mosques are managed in accordance with the above principles, of course mosques will teach peace, not intolerance and provocation. In this study, researchers will examine the strategy of preventing the spread of radicalism through strengthening the management of mosque takmir which refers to the teachings of Islam Aswaja Annabdliyah that consistently teaches tolerance and moderation.

\section{Method}

This research uses a descriptive qualitative study. Theoretically, qualitative research is research with the aim of understanding phenomena about what is experienced by research subjects such as behavior, perception, motivation, action, holistically and by way of descriptions in the form of words, in specific natural contexts and utilizing various natural methods. ${ }^{24}$ This research describes systematically and comprehensively about strategies to prevent radicalism in mosques by strengthening the management of Aswaja Annabdliyab Islamic-based mosque takmir in Kandangan Subdistrict, Temanggung Regency. In this area, there are several mosques that have no management of the takmir and have the potential to be penetrated by radicals.

The data source in this study consisted of primary and secondary data. The primary data are data directly obtained from informants in the sub-district and village government structures, the Nahdlatul Ulama Mosque Takmir Institution (LTM NU) in Temanggung, and mosque takmir in the Kandangan District area. Primary data was also excavated from the target of the mosque takmir management program in the Kandangan Sub-district, especially in four villages. Secondary data are data related to research, such as takmir management data, physical building

\footnotetext{
${ }^{22}$ Fathoni, Islam Ablussunnah Waljama'ah (Sejarah, Pemikiran, Dan Dinamika NU Di Indonesia), 186-87.

${ }^{23}$ Fathoni, 126. 6.

${ }^{24}$ Lexy J. Moleong, Metodologi Penelitian Kualitatif, II (Bandung: PT. Remaja Rosdakarya, 2005),

Khazanah, Vol. 17 (2), 2019 
data, and mosque contents, and mosque maintenance in four villages, namely Blimbing Village, Kedawung Village, Baledu Village, and Margolelo Village.

The data collection techniques used in this research are observation, interviews, and documentation regarding mosque takmir in the Kandangan Subdistrict area which was conducted on March 25, 2019, to May 8, 2019. It was in line with the date of STAINU Temanggung Community Service Program (KKN) in the academic year 2018-2019. Data analysis used in this study was descriptive qualitative analysis by presenting factual information from the village government and LTM NU Temanggung relating to the management of the mosque. The aim is to make a systematic, factual, and accurate description or description of the facts, characteristics and phenomena of the management of mosque takmir by strengthening Aswaja Annahdliyah based Islamic management to prevent the entry of radicalism.

\section{Discussion}

\section{Profile of the Mosque has Prospective Radicalism in Temanggung}

The phenomenon of terrorism of radical group capture is not only in urban areas such as Surakarta but also in Temanggung Regency. In the City of Tobacco, news of radicalism continues to emerge from year to year. In 2011, there is riot in Temanggung due to a blasphemy case. In February 2018, the Police force of Anti-Terrorism (The Densus 88 Team) arrested the suspected terrorist network AN. He was arrested at the Sudirman-Kranggan street grocery store, Temanggung, which allegedly had a network with the Adi Jihadi group, both of which had attended military training in Basilan, in the southern Philippines for war purposes. $^{25}$

The Densus 88 arrested a teenager named Dita Siska Milenia, a resident of Braman Hamlet, Jambon Village, Gemawang Subdistrict, Temanggung who was suspected of stabbing the police at Mako Brimob Kelapa Dua, Depok, West Java, Saturday 12 May 2018. She was arrested along with Siska Nur Azizah, Ciamis residents, West Java at Mako Brimob. Their arrests are closely related to radical behavior, in addition to veiling, they want to help terrorism inmates by attacking the police who have finally been foiled. ${ }^{26}$ In May 2018, the editor of Asy Syariah Magazine reported Tabayun.com cyber media to the police because they felt aggrieved by the news calling the magazine to spread the ideology of terror through Darul Atsar Kedu Islamic Boarding School (PP), Temanggung. The magazine was distributed in schools, mosques, village offices, Muspika, Office of Religious Affairs (KUA), and others. ${ }^{27}$

${ }^{25}$ Damar Sinuko, 'Terduga Teroris Temanggung Ditangkap Densus Di Toko Sembako', Cnnindonesia.Com, February 2018.

${ }^{26}$ Didik Dono Hartono, 'Densus 88 Tangkap Gadis Asal Temanggung Terkait Teror Di Mako Brimob', Inews.Id, May 2018.

${ }^{27}$ Dutaislam.com, 'Membantah Disebut Menyebar Ideologi Teror, Bukan Klarifikasi Dulu, Pihak PP Darul Atsar Lapor Polisi', Dutaislam.Com, May 2018. 
In February 2019, the police arrested a man with the initials Triyono Wagimin Atmo aka Andalus aka Abu Hilwa. Abu Hilwa is a terrorist who is included in the Densus 88 People Search List (DPO) who is a member of the Jamaah Ansharut Daulah (JAD). He was arrested on the Geneng Ring Road, Kertosari, Temanggung. ${ }^{28}$ If not stopped, the same phenomenon will continue to emerge because the spread of radicalism from remote villages to urban areas. One of the places where the spread of radicalism is through mosques.

Based on data from the Mosque Information System (Simas) of the Ministry of Religion, from 20 sub-districts in Temanggung until May 2019 there were 1613 mosques. The number consists of Jami mosques, large mosques, historic mosques, and mosques in public places. While the mosques in the Kandangan District area numbered 104 mosques. ${ }^{29}$ From the data of the Management Board of the Nahdlatul Ulama (PCNU) Temanggung and the Nahdlatul Ulama Mosque Takmir Institute (LTM NU) in Temanggung in 2019, only 1284 mosques are affiliated with NU. In Kandangan Subdistrict itself, especially in Blimbing Village, Kedawung Village, Baledu Village, and Margolelo Village, NU residents there are very minimal, so the management of the mosque runs as it is. Because the NU community is minimum, and a minimal number of mosque manager from NU circles, so it is easy for radicals to be in the mosque; radicals are free and not afraid of entering mosque management.

From information from the sub-district and village governments, especially in Blimbing Village, Kedawung Village, Baledu Village, and Margolelo Village, there are several potential groups of organizations that want to control the mosque. Quantitatively, there are two mosques that have been controlled by them and the rest are still safe and alert. This happened because of the lack of management of the takmir which upheld tolerance and moderation without opposing religion and culture and organizationally under the NU LTM.

They make moves and strategies with several modes. First, donating money to mosque administrators on a large scale so that the mosque administrators lost the power to control their actions. Second, taking over the certificate of the mosque by forcing it into the management of the mosque's mosque. Third, offer a study by bringing in radical religious texts specifically from the Surakarta and Yogyakarta regions. Fourth, against the policy of the village government, especially in Blimbing Village, which has been infiltrated by mosque administrators inhabited by radical groups. Although they are not radical in nature (movement), their ideological pattern prefers to contrast nationalism and Islamic values that fall into the categories of fikrah (thoughts) and aqeedah (beliefs).

Information from the Hamlet Heads in the four villages also stated that the mosques which they controlled had been far from activities that smelled of

${ }^{28}$ Harianjogja.com, 'Teroris Yang Ditangkap Di Temanggung Dijebloskan Ke Sel Khusus Agar Tak Sebarkan Radikalisme', Harianjogja.Com, February 2019.

29 simas.kemenag.go.id, 'Daftar Profil Masjid Di Prov. Jawa Tengah', Http:/ / Simas.Kemenag.Go.Id, May 2019.

Khazanah, Vol. 17 (2), 2019 
Islamic culture or traditions that had been carried out by the people long ago. Like the example of Suronan, Sadranan, Merti Dusun (clean village), tambourine, Topeng Ireng, Kuda Lumping, and others. Whereas the mosques which are still managed by residents with the management of Islam-based taqwa Aswaja Annahdliyah have never contrasted religion and culture so that the congregation and surrounding residents still preserve Islamic traditions and cultural heritage of their ancestors.

\section{The Lack of Management of the Mosque Takmir in Kandangan Temanggung}

Kandangan is one of the sub-districts in Temanggung Regency. Kandangan Sub-District has 16 villages, 108 hamlets, 101 RWs and 373 RTs with a distance of $8 \mathrm{Km}$ from Temanggung City with an area of 7,836 hectares. In 2012 the population of Kandangan Subdistrict was 47,668 people consisting of 24,031 men and 23,637 women. ${ }^{30}$ In Kandangan, the majority of citizens understand Islam Aswaja Annahdliyah or NU, but not all of the 104 mosques in Kandangan are affiliated with NU under the coordination of the NU LTM, especially in Blimbing Village, Kedawung Village, Baledu Village, and Margolelo Village.

The LTM NU Temanggung data points out that out of 104 mosques in Kandangan, only 96 were affiliated and applied to the management of Aswaja Annahdliyah, while the other 8 mosques were unclear in their management and outside of Aswaja Annahdliyah's management. Management in the four villages was also very weak.

From the results of interviews and observations, there were some lags in takmir mosques in these four villages. First, there is no planning, organizing, actuating, and controlling in the mosque takmir. Second, the lack of awareness of the mosque takmir administrators about the duties, functions, and principal obligations of the management in carrying out the wheels of the institutional organization of the mosque takmir. There are even five mosques which are no management at all and run without coordination and management. The mosque takmir is one of the organizations in the village, it is very vital in maintaining Islamic faith. Therefore, it is necessary to hold a mosque takmir management briefing to find out the tasks of each position. Third, there is a lack of proper management of mosque takmir such as chairman, secretary, treasurer, so that in the institution when there are problems often thrown.

As a result, the problem is not finished even becoming the embryo of a new problem. Fourth, the lack of knowledge of mosque takmir about correspondence so that in writing letters there were still errors and chaos. Fifth, lack of awareness in terms of financial management or assets of the mosque. Sixth, the lack of prayer equipment in some villages, especially in Blimbing Village, which caused the prayer equipment in the mosque to be inadequate.

30Temanggungkab.go.id, 'Profil Kecamatan Kandangan', Temanggungkab.Go.Id, May 2019. 
Seventh, the absence of the Aswaja Annahdliyah Islamic management system from the aspect of idarah (management of the physical building of the mosque), imarah (management of activities that enliven the mosque), and riayah (management of mosque cleanliness). Eighth, the absence of Amaliyah Aswaja Annahdliyah in the mosque. Ninth, the mosque is built outside NU residents and the takmir claims were managed outside of NU even in a perfunctory manner.

\section{Improving Islamic Aswaja Annahdliyah Takmir Mosque Management}

Management of LTM NU Temanggung with students from the KKN STAINU Temanggung approaches and the mosque's institutional strengthening programs are referred to the management of Aswaja Annahdliyah in the mosque of Blimbing Village, Kedawung Village, Baledu Village, and Margolelo Village. The management of the LTM NU Temanggung did not impose the eight mosques above to join NU. However, with the implementation of training activities through the mosque takmir management strengthening program, at the end of some mosques joined NU through the NU LTM.

Strengthening the management of takmir based on Aswaja Annahdliyah is carried out by conducting several activities. First, debriefing and mentoring of the target mosque takmir for three times. The training contained material about the management of the idarah (management of the physical building of the mosque), imarah (management of activities that enlivened the mosque), and riayah (management of cleaning the mosque).

In the aspect of idarah, takmir administrators and prospective takmir administrators were given an explanation of development planning, organizing, spatial arrangements, administrative order, management of the procurement of facilities and infrastructure, symbolization (giving of mosque boards), mosque supervision, and management of waqf land. Aspects of Imarah, takmir administrators and takmir administrators were given an explanation of worship management, motivation for congregational prayers, education of the Qur'an Education Center (Taman Pendidikan Al-Qur'an TPQ), Madrasah Diniyah (Madin), religious assembly or (Majelis taklim), social activities, Commemoration of Islamic Day (PHBI), orphanage benefits, management of zakat fitrah and zakat mall, youth mosque activities, Friday prayers and sermons, and others. The riayah, takmir officials and prospective takmir administrators were given an explanation of the management of building maintenance activities, environmental equipment, ablution places, the beauty of mosques, sound systems, including determining the direction of Qibla. 


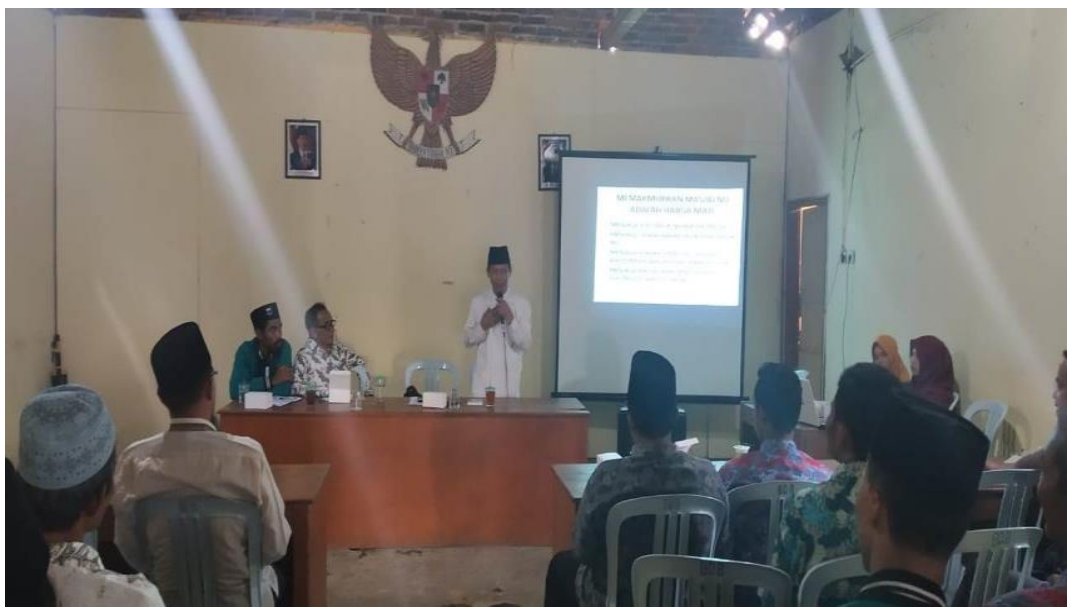

Figure 1:

Briefing of Mosque Takmir Management

from the Nahdlatul Ulama Mosque Takmir Institute (LTM NU) of Temanggung.

Second, establishing the Nahdlatul Ulama Mosque Takmir Institution (NU LTM) at the sub-district and village levels to oversee the activities of pilgrimage, imarah, and riayah, and ensure the implementation of takmir management from planning to evaluation. Third, making the takmir management of the mosque involves all elements, starting from the sub-district head, village head/village head, the NU Branch Representative Board (WMC) management, and takmir's core management. For the subdistrict head/village head to be made an advisor, then there is a protector filled with local Kiai / ulama from the NU MWC elements, chairman, secretary, treasurer, and administrators of the field of idarah, imarah, and riayah.

Fourth, creating syllabus/curriculum for obligatory religious activities such as prayer, educational activities such as discussions, seminars, studies, Bahtsul Masa'il, recitation, lectures, sermons, and ritual activities such as janjen, manaqiban, zibaan, tablilan, istighasah, mujahadah and more. All activities are based on the Aswaja Annahdliyah faith which prioritizes the values of at-tawassuth (middle/moderate), at-tawazun (balanced), al-i'tidal (perpendicular), and tasamub (tolerance). Activities in the mosque must also be oriented to the social aspects of the teachings of Aswaja Annahdliyah, namely Ukhuwah Islamiyah (brotherhood among Muslim followers), Ukhuwah Wataniyah (brotherhood between nationalities), and ukhuwah insaniyah (brotherhood of humanity).

Fifth, assigning officials to carry out their duties and maximize the function of the mosque. Starting from guarding mosque assets, waqf land, Aswaja Annahdliyah faithfulness that adheres to Islamic moderation, guarding mosques from the control or disturbance of radical groups, functioning mosques as places of worship, maintaining moderate Islamic aqidah, functioning of mosques as places of Islamic missionary rabmatan lil-alamin, place of education, economic empowerment, social services, and being the center of spreading tolerance. 
Sixth, in the physical sector, making the board of the mosque structure, mosque signpost, road instructions to the mosque, schedule of lecturers and transparency boards of the mosque, procurement of the Qur'an mushaf, yellow books (Kitab Kuning), mukena and sarongs, and mosque administration management as symbolic forms. Seventh, strengthening socio-economic empowerment in mosques by equipping management of zakat fitrah and malls, managing bodies, and making programs "clean movements of mosques" with time every Sunday at 08.00 WIB until completion.

From this program, May 8 2019, out of the eight mosques that had not joined the NU LTM, there were four mosques that had been formed by their takmir management and carried out programs according to the concept of LTM NU Temanggung. There are three mosques that do not want to join, one mosque has not been successfully embraced because there are two people who are affiliated with organizations that support the purification of Islam that has mastered the mosque. So that from the program target, only four have been managed with Aswaja Annahdliyah takmir management, while the other four have not been able to be embraced.

The impact of this program, until the end of June 2019, the management of the mosque had run normally because each element of LTM Nu, NU MWC, village government, and takmir administrators both controlled the performance and potential of groups offering radical Islamic studies. This Aswaja Annahdliyah Islam-based mosque takmir strengthening program can prevent potential radicalism in mosques, especially in four villages in Kandangan Subdistrict because although there are still four mosques that have not been successfully embraced, all of the mosques have implemented Aswaja Annahdliyah management that upholds the moderation of Islam.

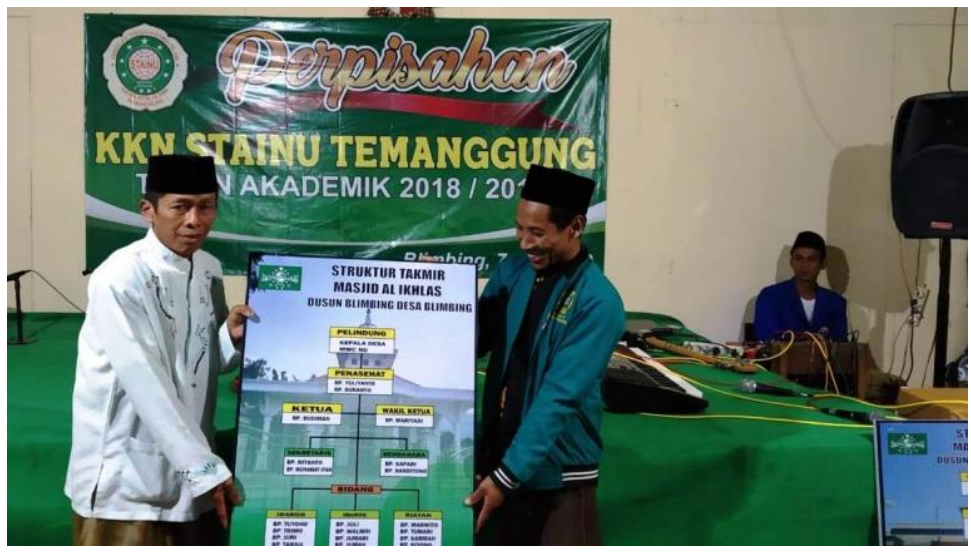

Figure 2:

Farewell student KKN at the same time inauguration, Submission of Letter of Management, and board of takmir structure of the mosque. 


\section{Opportunities and Challenges}

The efforts carried out by the STAINU KKN team together with the LTM NU Temanggung were aligned with the concept and theory of Talcott Parsons structural functionalism. The reason is that Parson's structural functionalism theory begins with four important schemes regarding functions for all systems of action, the scheme is known as the scheme of adaptation, goalattainment, integration, latency (AGIL) which can be done to preserve a culture. If analyzed, from the AGIL scheme, social reality in four villages in Kandangan Subdistrict has a relationship between the general public, mosque managers, and radical groups who want to control the mosque. If one of these community systems changes its pattern, especially in the management of moderate-based mosques, then other community systems will follow suit.

In this case, the culture in question is Islamic culture that upholds the values of Aswaja Annabdliyah starting from at-Tawassuth (middle/moderate), attawazun (balanced), al-itidal (perpendicular), and Tasamub (tolerance), and Ukbuwah Islamiyah (brotherhood among Muslim followers), Ukbuwah Wataniyah (brotherhood between the nations), and ukbuwah insaniyah (brotherhood of mankind) which can be realized through takmir of the mosque. When the mosque takmir has implemented the Aswaja Annahdliyah Islamic substance, the general public and radical groups will be affected to accept Aswaja Annahdliyah values from the mosque.

The AGIL scheme is carried out by the KKN STAINU Temanggung and LTM NU Temanggung teams in preventing radicalism from entering the mosque through strengthening the mosque takmir. In the adaptation scheme, the KKN team of STAINU Temanggung and LTM NU Temanggung had done it in strategies number 1 and 2 . This adaptation was carried out by adapting to maintaining the management of the mosque from the aspect of idarah, imarah, and riayah from planning, organizing, acting, and evaluating accordingly the type and character of the local community with an Islamic moderation mission as the Islamic perspective of Aswaja Annahdliyah.

In the goal scheme, the KKN team of STAINU Temanggung and LTM NU Temanggung had done it on strategies number 3, 4, 5, 6, and 7. The KKN Team of STAINU Temanggung and LTM NU of Temanggung not only forced mosques to join NU, but also invited administrators or prospective takmir administrators fix the management, administration, and physical sector of the mosque building. In the integration scheme, the KKN team of STAINU Temanggung and LTM NU Temanggung have done it in strategies number 4, 5, 6, and 7. Its form by integrating the management of mosques is not only for worship activities, but also in educational activities, religious rituals, economic empowerment, and keep the assets of the mosque to develop. In the scheme of latency or the selection of patterns that already exist, it has been implemented in strategies number 1 and 2 by maintaining and improving the patterns of management of existing mosques by strengthening them on aspects of idarah, 
imarah, and Aswaja Annahdliyah based riayah from aspects of fikrah, aqidah, harakah and amaliyah.

Although it can be said to be a success, there are still challenges arising from internal takmir and external mosque takmir that have been formed by implementing Aswaja Annahdliyah based mosque management. In the internal aspects, namely limited access to the city center, low human resources, and lack of comprehensive knowledge about the management of mosque takmir. While external aspects, there are four mosques that are still controlled by radical Islamic groups, massive offer of studies in mosques from radical groups, the presence of leaflets with radical content in mosques, and others.

The opportunity to strengthen Islamic moderation as a bulwark for the prevention of radicalism is very large with the formation of a mosque takmir management under the LTM NU, because with early detection through fostering an awareness of the importance of mosque functions to takmir, they are more concerned with mosques with evidence of the many people who propose themselves become takmir management. By this indicator, the management of the Aswaja Annahdliyah mosque takmir is a provision to prevent the entry of radicalism in the mosque. Because, takmir mosque is not everything, but everything can start from there!

\section{Conclusion}

Radicalism has the potential to enter the mosque is very high and must be prevented through strengthening the Aswaja Annahdliyah Islamic mosque takmir. Of the eight mosques in Kandangan Subdistrict, only four mosques can be fostered and apply the takmir management of the Aswaja Annahdliyah based. The reinforcement strategy consists of seven. First, strengthening the management of idarah (management of the physical building of the mosque), imarah (management of activities that enliven the mosque), and riayah (management of cleaning the mosque). Second, formed the Nahdlatul Ulama Mosque Takmir Institution (LTM $\mathrm{NU}$ ) at the sub-district and village levels to oversee the activities of idarah, imarah, and riayah, and ensure the implementation of takmir management from planning to evaluation. Third, forming the management of the takmir involves all elements. Fourth, make the syllabus/curriculum for compulsory worship activities, educational activities, and ritual activities. Fifth, assign officials to carry out their duties and maximize the function of the mosque. Sixth, strengthening administrative management and symbolizing mosques. Seventh, strengthening social-economic empowerment in mosques.

The strategy of strengthening the mosque takmir management has been aligned with Talcott Parsons's structural functionalism theory with the AGIL scheme. Starting from the aspects of management of idarah, imarah, and riayah in mosques that have been formed takmir under the LTM NU. There are challenges and opportunities faced. In the internal aspects, the challenges and opportunities are limited access to the city center, low human resources, and lack of comprehensive knowledge about 
the management of the mosque. While the external aspects, there are four mosques which are still controlled by radical Islamic groups, and often there are offers of studies in mosques from radical groups.

\section{References}

Abdusshomad, Muhyidin. 'Karakter Tawassuth, Tawazun, I'tidal, dan Tasamuh Dalam Aswaja'. Nu.or.Id. March 2009.

Abshor, Muhammad Ulil. 'Peran Sufisme dalam Mengatasi Paham Islam Radikal Di Indonesia'. Al-Banjari: Jurnal Ilmiah Ilmu-Ilmu Keislaman 18 (2019): 153-68. https://dx.doi.org/10.18592/al-banjari.v18i1.2540.

A'la, Abd. 'The Genealogy of Muslim Radicalism in Indonesia: A Study Of The Roots And Characteristics of the Padri Movement'. Journal of Indonesian Islam 2 (2008): 267-99. http://dx.doi.org/10.15642/JIIS.2008.2.2.267-299.

Al-Makassary, Ridwan. 'Examining Jakarta Office Mosques: Islamic Teaching Practices and Views of Islamic Ideological Issues'. IJIMS: Indonesian Journal of Islam and Muslim Societies 3 (2013): 121-48. http://dx.doi.org/10.18326/ijims.v3i1.121-148.

Amany, Tsamara. "Ini Dia 6 Ormas Yang Harus Dibubarkan Pemerintah". redaksiindonesia.com. January 2016.

Arifin, Syamsul. 'Islamic Religious Education and Radicalism in Indonesia: Strategy of Deradicalization Through Strengthening the Living Values Education'. Indonesian Journal of Islam and Muslim Societies 6 (2016): 93-126. http://dx.doi.org/10.18326/ijims.v6i1.93-126.

Dutaislam.com. 'Membantah Disebut Menyebar Ideologi Teror, Bukan Klarifikasi Dulu, Pihak PP Darul Atsar Lapor Polisi’. Dutaislam.Com. May 2018.

Fathoni, Aceng Abdul Aziz DY; M. Harfin Zuhdi Zamzami M; Afwan Faizin; Sulthonul Huda; Sulthon. Islam Ahlussunnah Waljama'ah (Sejarah, Pemikiran, Dan Dinamika NU Di Indonesia). II. Jakarta: PP Lembaga Pendidikan Ma'arif NU, 2015.

Halim, Devina. 'Penjelasan BIN soal 41 Masjid di Lingkungan Pemerintah Terpapar Radikalisme'. KOMPAS.com. Accessed 20 December 2019. https:/ / sains.kompas.com/read/2018/11/20/19443281/penjelasan-binsoal-41-masjid-di-lingkungan-pemerintah-terpapar-radikalisme.

Hamid, M. Zaki Mubarok; Ahmad Fauzi Abdul. 'The Rise of Radicalism and Terrorism in Indonesia and Malaysia'. RISEA : Review of Islam in Southeast Asia 1 (2018): 29-43.

Harianjogja.com. 'Teroris Yang Ditangkap Di Temanggung Dijebloskan Ke Sel Khusus Agar Tak Sebarkan Radikalisme’. Harianjogja.Com. February 2019. 
Hartono, Didik Dono. 'Densus 88 Tangkap Gadis Asal Temanggung Terkait Teror Di Mako Brimob’. inews.id. May 2018.

Huda, Ilyya Muhsin; Nikmah Rochmawati; Muhammad Chairul. 'Revolution of Islamic Proselytizing Organization: From Islamism to Moderate'. Qudus International Journal of Islamic Studies2019 7 (2019): 45-70. http://dx.doi.org/10.21043/qijis.v7i1.5076.

Koiri, Rahmawati Rahmawati; Kasim Yahiji; Choirul Mahfud; Jauharoti Alfin; Much. 'Chinese Ways of Being Good Muslim: From the Cheng Hoo Mosque to Islamic Education and Media Literacy'. Indonesian Journal of Islam and Muslim Societies 8 (2019): 225-52. http://dx.doi.org/10.18326/ijims.v8i2.225-252.

Maulana, Dirga. 'The Exclusivism of Religion Teachers: Intolerance and Radicalism in Indonesian Public Schools'. Studia Islamika 24 (2017): 395-401. http://dx.doi.org/10.15408/sdi.v24i2.5707.

Moleong, Lexy J. Metodologi Penelitian Kualitatif. II. Bandung: PT. Remaja Rosdakarya, 2005.

Muzakki, Akh. 'The Roots, Strategies, and Popular Perception of Islamic Radicalism In Indonesia'. Journal of Indonesian Islam (JIIS) 8 (2014): 1-22. http://dx.doi.org/10.15642/JIIS.2014.8.1.1-22.

Nathaniel, Felix. 'Soal Masjid Terpapar Radikalisme, BIN: Yang Radikal Penceramahnya', tirto.id. November 2018.

Saputra, Muhammad Nida' Fadlan; Rangga Eka. 'Islam, Radicalism, Democracy, and Global Trends in Southeast Asia'. Studia Islamika 24 (2017): 643-47. https://doi.org/10.15408/sdi.v24i3.6566.

simas.kemenag.go.id. 'Daftar Profil Masjid di Prov. Jawa Tengah'. Http:/ / simas.kemenag.go.id. May 2019.

Sinuko, Damar. 'Terduga Teroris Temanggung Ditangkap Densus di Toko Sembako'. cnnindonesia.com. February 2018.

Surahman, Mohammad Fahrur Rozi; Fajar. 'Internalisasi Nilai-Nilai Pendidikan Agama Islam Dalam Rangka Memperkokoh NKRI: Melawan Paham Radikalisme Dan Arus Isu Terorisme Di Remas Robiatul Adhawiyah Dan Remas Al-Falah Desa Ponteh Kecamatan Galis Kabupaten Pamekasan'. Jurnal Pengabdian Masyarakat 4 (2019): 22-29. https://doi.org/10.30996/jpm17.v4i1.1992.

Syafar, Muhammad. 'Pemberdayaan Masyarakat Berbasis Masjid untuk Menangkal Radikalisme Islam di Banten'. Lembaran Masyarakat: Jurnal Pengembangan Masyarakat Islam 4 (2018): 103-22. http://dx.doi.org/10.32678/lbrmasy.v4i2.1185. 
Hamidulloh Ibda \& Ziaul Khaq

Temanggung, Lembaga Takmir Masjid (LTM) Nahdlatul Ulama Kabupaten. Buku Saku Takmir. 1st ed. Temanggung: PCNU Temanggung, 2016.

Temanggungkab.go.id. 'Profil Kecamatan Kandangan'. Temanggungkab.Go.Id. May 2019.

Thenu, Stefi. 'Selabaran Radikal di Masjid Harus Ditangkal'. Beritasatu.Com. November 2016.

Ummah, Sun Choirol. 'Akar Radikalisme Islam di Indonesia'. Humanika: Kajian Ilmiah Mata Kuliah Umum 12 (2012): 112-24. http://dx.doi.org/10.21831/hum.v12i1.3657.

W, Rama Prasetyo. 'Pengurus Takmir Kampus di Purwokerto Dilibatkan Untuk Pencegahan Gerakan Radikalisme’. rri.co.id. October 2018. 